\title{
Evaluation of the in vitro glycemic index of a fiber-rich extruded breakfast cereal produced with organic passion fruit fiber and corn flour
}

\author{
Avaliação do índice glicêmico in vitro de cereal matinal extrudado \\ produzido com farinha de milho e farelo de maracujá orgânicos
}

Maria Gabriela Vernaza LEORO ${ }^{1}$, Maria Teresa Pedrosa Silva CLERICI ${ }^{1}$, Yoon Kil CHANG ${ }^{1}$, Caroline Joy STEEL ${ }^{1,2 *}$

\begin{abstract}
The aim of this study was to determine the influence of process parameters and Passion Fruit Fiber (PFF) addition on the Glycemic Index (GI) of an extruded breakfast cereal. A $2^{3}$ Central Composite Rotational Design (CCRD) was used, with the following independent variables: raw material moisture content (18-28\%), $2^{\text {nd }}$ and $3^{\text {rd }}$ barrel zone temperatures $\left(120-160{ }^{\circ} \mathrm{C}\right)$, and PFF (0-30\%). Raw materials (organic corn flour and organic PFF) were characterized as to their proximate composition, particle size, and in vitro GI. The extrudates were characterized as to their in vitro GI. The Response Surface Methodology (RSM) and Principal Component Analysis (PCA) were used to analyze the results. Corn flour and PFF presented 8.55 and $7.63 \%$ protein, 2.61 and $0.60 \%$ fat, 0.52 and $6.17 \%$ ash, 78.77 and $78.86 \%$ carbohydrates $(3$ and $64 \%$ total dietary fiber), respectively. The corn flour particle size distribution was homogeneous, while PFF presented a heterogeneous particle size distribution. Corn flour and PFF presented values of GI of 48 and 45, respectively. When using RSM, no effect of the variables was observed in the GI of the extrudates (average value of 48.41), but PCA showed that the GI tended to be lower when processing at lower temperatures $\left(<128^{\circ} \mathrm{C}\right)$ and at higher temperatures $\left(>158^{\circ} \mathrm{C}\right)$. When compared to white bread, the extrudates showed a reduction of the GI of up to $50 \%$, and could be considered an interesting alternative in weight and glycemia control diets.

Keywords: glycemic index; breakfast cereal; passion fruit fiber; thermoplastic extrusion.
\end{abstract}

\section{Resumo}

Este trabalho visou avaliar o Índice Glicêmico (IG) in vitro de cereal matinal extrudado à base de farinha de milho (MI) e farelo de maracujá (MA) orgânicos. As matérias-primas foram caracterizadas (composição centesimal, tamanho de partícula e IG) e foi utilizado um planejamento experimental completo $2^{3}$ para a obtenção dos extrudados, nos quais as variáveis independentes foram: teor de umidade da matéria-prima (18 a $28 \%$ ), temperatura de extrusão $\left(120\right.$ a $\left.160^{\circ} \mathrm{C}\right)$ e adição de farelo de maracujá ( 0 a 30\%), tendo o IG como resposta analisada pela Metodologia de Superfície de Resposta (MSR) e Análise de Componentes Principais (ACP). MI e MA apresentaram 8,5 e 7,63\% de proteína, 2,61 e 0,60\% de gordura, 0,52 e $6,17 \%$ de cinzas, 78,77 e 78,86\% de carboidratos (3 e $64 \%$ de fibra alimentar total) e 48 e 45 de IG, respectivamente. MI teve distribuição homogênea de partículas; já a de MA foi heterogênea. A MSR não mostrou variação significativa no IG (média = 48,41), mas a ACP indicou que o IG tende a ser menor em extrudados com temperaturas de extrusão abaixo de $128^{\circ} \mathrm{C}$, e maior acima de $158^{\circ} \mathrm{C}$. $\mathrm{O}$ cereal matinal apresentou redução de até $50 \%$ no IG, quando comparado com pão branco (100\%), podendo ser benéfico à saúde.

Palavras-chave: índice glicêmico; cereal matinal; farelo de maracujá; extrusão termoplástica.

\section{Introduction}

The consumption of dietary fiber plays an important role in the prevention of various diseases including colon cancer, coronary heart disease, obesity, diabetes, and gastrointestinal disorders. Insoluble fiber, which is often found in cereals, is mainly related to intestinal regulation, whereas soluble fiber, mainly found in fruits and vegetables, is involved in lowering blood cholesterol and glucose adsorption (THEBAUDIN et al., 1997; CHAU; HUANG, 2004). A reduction in the Glycemic Index (GI) of starch-based foods can be obtained with the use of fibers which could be beneficial to diabetic patients by aiding in the control of postprandial insulin release (ROBERTS, 2000).
Breakfast cereals have been widely consumed in the last decades and the main process used to produce them has been thermoplastic extrusion. This process permits the manufacturing of a large variety of products with few modifications of equipment and a proper control of operational parameters (MERCIER; LINKO; HARPER, 1998).

The aim of this study was to evaluate the GI of an extruded breakfast cereal based on corn flour and different concentrations of commercial organic Passion Fruit Fiber (PFF), varying the following extrusion parameters: raw material moisture content and $2^{\text {nd }}$ and $3^{\text {rd }}$ barrel zone temperatures, using a $2^{3}$ central composite rotational design.

Recebido para publicação em $7 / 10 / 2008$

Aceito para publicação em 16/5/2009 (003863)

${ }^{1}$ Department of Food Technology, Faculty of Food Engineering, State University of Campinas, Brazil

2 Cereal Laboratory, Department of Food Technology, Faculty of Food Engineering, State University of Campinas, CP 6121, CEP 13083-862, Campinas - SP, Brazil,

E-mail: steel@fea.unicamp.br

${ }^{*}$ A quem a correspondência deve ser enviada 


\section{Material and methods}

\subsection{Material}

Commercial organic Passion Fruit Fiber (PFF) was obtained from Sítio Boa Esperança, Guaratinguetá - SP, Brazil. PFF is a byproduct of the passion fruit pulp extraction process. The peel, without pulp and seeds, is used as fiber source.

The commercial organic corn flour was obtained from Cooperativa Agropecuária Alto Uruguai Ltda. Cotrimaio, Três de Maio - RS, Brazil.

\subsection{Methods}

\section{Characterization of the raw materials}

Corn flour and passion fruit fiber were characterized as to their proximate composition: i) moisture, according to the Approved Method 44-15A (AMERICAN..., 2000); ii) fat, according to the Approved Method 30-10 (AMERICAN..., $2000)$; iii) protein, according to the Approved Method 46-30 (AMERICAN..., 2000); iv) ash, according to the Approved Method 08-01 (AMERICAN..., 2000); v) soluble, insoluble and total dietary fiber, according to the Approved Methods 985.29 and 991.43 (ASSOCIATION..., 1995); vi) carbohydrates were calculated subtracting moisture, fat, protein and ash contents from 100. These analyses were carried out in triplicate.

Raw materials were also characterized as to particle size. Particle size was determined according to the AOAC Method 965.22 (ASSOCIATION..., 1995), modifying the series of sieves, which varied from 20 to 100 mesh.

\section{Extrusion process}

For the production of the extrudates, a $2^{3}$ Central Composite Rotational Design (CCRD) was followed and the Response Surface Methodology (RSM) was used to evaluate the effects of raw material moisture content, $2^{\text {nd }}$ and $3^{\text {rd }}$ barrel zone temperatures, and added passion fruit fiber on the in vitro Glycemic Index (GI) of the extrudates, with levels of variation as shown in Table 1.

The processing was carried out in a single-screw laboratory extruder (20 L/D Brabender, Germany), keeping feeding rate (70 g/minute), $1^{\text {st }}$ barrel zone temperature $\left(80^{\circ} \mathrm{C}\right)$, screw speed (130 rpm), screw compression ratio (3:1), and die diameter (3.4 mm) constant.

All extrudates produced were dried in a hot air circulation oven with air renewal, model TE 394/2 (Tecnal, Brazil), at $80{ }^{\circ} \mathrm{C}$ for 1 hour. They were then ground to a flour and sieved to standardize particle size ( $<100 \mathrm{mesh})$ for the determination of the in vitro glycemic index.

Table 1. Levels of the independent variables.

\begin{tabular}{lrrrrr}
\hline \multicolumn{1}{c}{$\begin{array}{c}\text { Independent } \\
\text { variables }\end{array}$} & $\begin{array}{c}-1.68 \\
(-\alpha)\end{array}$ & -1 & 0 & +1 & $\begin{array}{c}+1.68 \\
(+\alpha)\end{array}$ \\
\hline Passion fruit fiber $(\%)$ & 0 & 6 & 15 & 24 & 30 \\
Raw material moisture content $(\%)$ & 18 & 20 & 23 & 26 & 28 \\
Extrusion temperature $\left({ }^{\circ} \mathrm{C}\right)$ & 120 & 128 & 140 & 152 & 160 \\
\hline
\end{tabular}

\section{In vitro glycemic index analysis}

The in vitro Glycemic Index (GI) of the raw materials and extrudates was determined according to the methodology described by Goñi et al. (1997), with the following modifications: glucose concentration was determined using a GOD-PAD glucose kit (Laborlab, Brazil) and the color reaction was measured in a UV/VIS spectrophotometer, model DU 70 (Beckman, USA), at $\lambda=505 \mathrm{~nm}$.

Glucose digestion rate was expressed through the percentage of glucose in each sample (mg glucose.100 $\mathrm{mg}^{-1}$ sample) at each time interval $(0,30,60,90,120,150$, and 180 minutes). Hydrolysis curves were built (disregarding the value at time 0 ), and the area below the hydrolysis curves was calculated (AHC). The Hydrolysis Index (HI) for each sample was calculated as the ratio between the $\mathrm{AHC}$ of each sample and the $\mathrm{AHC}$ of white bread, used as reference, and expressed in percentage, as reported by Goñi et al. (1997). Finally, the GI was calculated according to Equation 1:

$G I=39.71+0.549 * H I$

where GI = Glycemic Index (\%); and HI = Hydrolysis Index (\%).

\section{Comparison between the GI of the raw materials and of the extrudates}

The extrudates with the highest and lowest GI values were compared with the GI determined for the raw materials (passion fruit fiber and corn flour) and with white bread, used as reference. The hydrolysis curves were built as described in the section above (In vitro glycemic index analysis).

\section{Statistical analysis}

The analysis of variance (ANOVA) and the Tukey test, at a 95\% significance level, were carried out to determine statistical differences in the particle size of each raw material using the SAS program version 6 (SAS Institute, USA).

To analyze the results of the GI of the extrudates, the Response Surface Methodology was applied using the Statistica software version 5.5 (Statsoft, USA). The analysis of variance (ANOVA) was carried out using the coded values of the independent variables. The significance of the regression coefficients and the lack of fit were evaluated, at a $90 \%$ significance level, through the $\mathrm{F}$ test. The coefficient of determination $\left(\mathrm{R}^{2}\right)$ was also calculated and analyzed. For comparison and an easy visualization of the influence of fiber addition and extrusion parameters studied on the GI, Principle Component Analysis (PCA) was also carried out, using the SAS program, version 6 (SAS Institute, USA) and the graphic representation was made using Origin, version 4.1 (Microcal, USA).

\section{Results and discussion}

\subsection{Characterization of the raw materials}

The proximate compositions of the raw materials, corn flour, and passion fruit fiber are presented in Table 2. Corn flour 
presented high carbohydrate content, predominantly starch, and low fiber content, justifying the interest in enriching breakfast cereals based on corn flour with fibers. The results of corn flour composition are in accordance with Ferreira (2006).

It can be observed that passion fruit fiber contains a high content of total dietary fiber $(64.11 \%)$ presenting significant contents of soluble fiber (13.96\%), different from corn flour which presented a lower total dietary fiber content (3.68\%), of which only $0.31 \%$ was soluble fiber. Matsuura (2005) reported $67.5 \%$ total dietary fiber in passion fruit fiber obtained from the albedo of the fruit, of which $35.8 \%$ was insoluble fiber and $31.7 \%$ was soluble fiber. When the results are compared, it can be seen that the soluble fiber/insoluble fiber ratio was lower in our study $(0.28)$ than that reported by this researcher $(0.88)$. This fact is attributed, in part, to the use of whole passion fruit fiber (including the peel) in this project, while Matsuura (2005) used only the albedo. Passion fruit fiber also presented considerable quantities of protein (7.63\%) and ash (6.17\%). The ash content represents the minerals present in the material, such as sodium, potassium, and iron (MATSUURA, 2005).

Corn flour presented a homogeneous particle size distribution, with $85 \%$ between 32 and 60 mesh, while PFF presented a heterogeneous particle size distribution, with $29 \%$ between 20 and 32 mesh, 32\% between 32 and 60 mesh and 22.5\% smaller than 100 mesh, as shown in Table 3.

The Glycemic Index (GI) was 48 for corn flour and 45 for PFF. These values are much lower than those mentioned by Goñi et al. (1997) for white bread (100), spaghetti (78), rice (81), biscuits (79), beans (60), peas (74), boiled potatoes (101), and potato chips (74) and similar to those mentioned for lentils (42) and chickpeas (47) (GOÑI et al., 1997; CHUNG et al., 2008).

Table 2. Proximate composition (\%) of the raw materials.

\begin{tabular}{lcc}
\hline Component & Corn flour & Passion fruit fiber \\
\hline Moisture & $9.55 \pm 0.06$ & $6.74 \pm 0.06$ \\
Fat & $2.61 \pm 0.01$ & $0.60 \pm 0.07$ \\
Protein & $8.55 \pm 0.08$ & $7.63 \pm 0.14$ \\
Ash & $0.52 \pm 0.01$ & $6.17 \pm 0.03$ \\
Carbohydrates & 78.77 & 78.86 \\
Total dietary fiber & $3.68 \pm 0.01$ & $64.11 \pm 0.06$ \\
Insoluble & $3.37 \pm 0.02$ & $50.16 \pm 0.08$ \\
Soluble & $0.31 \pm 0.1$ & $13.96 \pm 0.02$ \\
\hline
\end{tabular}

${ }^{\star}$ Calculated by difference, includes the dietary fiber fraction.

Table 3. Particle size distribution of corn flour and Passion Fruit Fiber (PFF).

\begin{tabular}{lccc}
\hline Mesh & Opening $(\mu \mathrm{m})$ & Corn flour $(\%$ retained $)$ & PFF $(\%$ retained $)$ \\
\hline 20 & 840 & $0.72^{\mathrm{c}} \pm 0.30$ & $4.73^{\mathrm{e}} \pm 0.27$ \\
32 & 500 & $0.94^{\mathrm{c}} \pm 0.68$ & $29.38^{\mathrm{b}} \pm 0.68$ \\
60 & 250 & $85.21^{\mathrm{a}} \pm 2.40$ & $31.98^{\mathrm{a}} \pm 0.80$ \\
80 & 177 & $8.65^{\mathrm{b}} \pm 1.39$ & $8.48^{\mathrm{d}} \pm 0.55$ \\
100 & 149 & $0.97^{\mathrm{c}} \pm 0.59$ & $3.00^{\mathrm{e}} \pm 0.10$ \\
Bottom & - & $3.54^{\mathrm{c}} \pm 1.88$ & $22.45^{\mathrm{c}} \pm 0.95$ \\
\hline
\end{tabular}

Means followed by the same superscript letter in the column are not significantly different $(\mathrm{p}<0.05)$.

\subsection{Extrudates}

The extruded products presented GI values between 47.93 and 49.74 , as can be observed in Table 4 . No references in literature using experimental design to evaluate the effects of the thermoplastic extrusion process and of the formulation on the GI of extruded products were found. Nonetheless, as previously mentioned (GOÑI et al., 1997), these values are much lower than those reported for other prepared foods, such as white bread, spaghetti, rice, biscuits, and boiled potatoes.

Analyzing Table 5, it can be observed that the only statistically significant effect $(\mathrm{p}<0.10)$ was process temperature. Also, the standard errors for all effects were high. Therefore, the mathematical model and the response surfaces were not considered for the GI as response, for, when eliminating the nonsignificant effects from the statistical analysis, the coefficient of determination $\left(\mathrm{R}^{2}\right)$ was reduced to less than $60 \%$, and the residues were high.

It was not possible to observe the effects of the variables studied on the GI through the RSM; thus, the average GI obtained for the extrudates (48.41) was considered. However, in order to tentatively select the processes that lead to the lowest GI values individually, Principal Component Analysis (PCA) was used. The results can be observed in Figure 1.

In Figure 1, it can be seen that PC1 (Principal Component 1) explained $96 \%$ of the responses for the GI; thus, the assays that led to the lowest GI values were Assays 2 and 4, which have the quantity of added PFF (24\%) and the extrusion temperature $\left(128^{\circ} \mathrm{C}\right)$ in common, although having raw material moisture contents of 20 and $26 \%$, respectively.

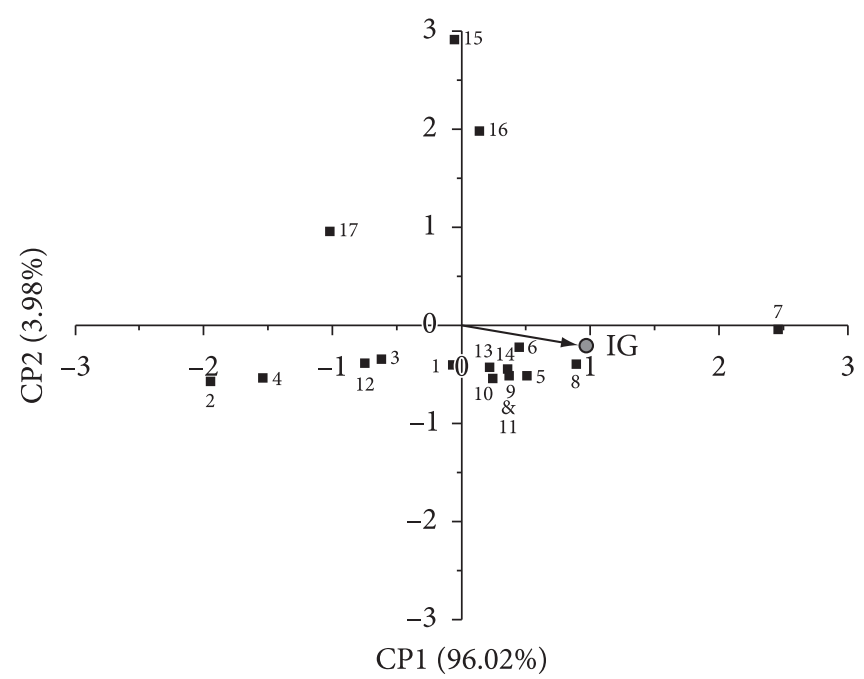

Figure 1. Principal Component Analysis (PCA) for in vitro Glycemic Index (GI) of extrudates produced with passion fruit fiber and corn flour. $1=6 \%$ PFF, $20 \% \mathrm{MC}, 128^{\circ} \mathrm{C} ; 2=24 \%$ PFF, $20 \% \mathrm{MC}, 128^{\circ} \mathrm{C} ; 3=6 \% \mathrm{PFF}$, $26 \% \mathrm{MC}, 128^{\circ} \mathrm{C} ; 4=24 \% \mathrm{PFF}, 26 \% \mathrm{MC}, 128^{\circ} \mathrm{C} ; 5=6 \% \mathrm{PFF}, 20 \% \mathrm{MC}$, $152{ }^{\circ} \mathrm{C} ; 6=24 \% \mathrm{PFF}, 20 \% \mathrm{MC}, 152{ }^{\circ} \mathrm{C} ; 7=6 \% \mathrm{PFF}, 26 \% \mathrm{MC}, 152{ }^{\circ} \mathrm{C}$; $8=24 \%$ PFF, $26 \% \mathrm{MC}, 152{ }^{\circ} \mathrm{C} ; 9=0 \% \mathrm{PFF}, 23 \% \mathrm{MC}, 140{ }^{\circ} \mathrm{C} ; 10=30 \%$ PFF, $23 \% \mathrm{MC}, 140{ }^{\circ} \mathrm{C} ; 11=15 \% \mathrm{PFF}, 18 \% \mathrm{MC}, 140{ }^{\circ} \mathrm{C} ; 12=15 \% \mathrm{PFF}$, $28 \% \mathrm{MC}, 140{ }^{\circ} \mathrm{C} ; 13=15 \%$ PFF, $23 \% \mathrm{MC}, 120^{\circ} \mathrm{C} ; 14=15 \%$ PFF, $23 \%$ $\mathrm{MC}, 160{ }^{\circ} \mathrm{C} ; 15=15 \% \mathrm{PFF}, 23 \% \mathrm{MC}, 140{ }^{\circ} \mathrm{C} ; 16=15 \% \mathrm{PFF}, 23 \% \mathrm{MC}$, $140{ }^{\circ} \mathrm{C} ; 17=15 \%$ PFF, $23 \% \mathrm{MC}, 140{ }^{\circ} \mathrm{C} ; 18=15 \% \mathrm{PFF}, 23 \% \mathrm{MC}, 140{ }^{\circ} \mathrm{C}$ $\mathrm{PFF}=$ passion fruit fiber and $\mathrm{MC}=$ raw material moisture content. $\mathrm{PC} 1=$ Principal Component 1 and PC2 = Principal Component 2. 
Table 4. In vitro Glycemic Index (GI) of extrudates produced with passion fruit fiber and corn flour.

\begin{tabular}{crrrrrcc}
\hline Assay & $\mathrm{X}$ & $\mathrm{Y}$ & $\mathrm{Z}$ & $\mathrm{x}$ & $\mathrm{y}$ & $\mathrm{Z}$ & Glycemic index \\
\hline 1 & -1 & -1 & -1 & 6 & 20 & 128 & 48.71 \\
2 & +1 & -1 & -1 & 24 & 20 & 128 & 47.93 \\
3 & -1 & +1 & -1 & 6 & 26 & 128 & 48.47 \\
4 & +1 & +1 & -1 & 24 & 26 & 128 & 48.10 \\
5 & -1 & -1 & +1 & 6 & 20 & 152 & 48.96 \\
6 & +1 & -1 & +1 & 24 & 20 & 152 & 48.91 \\
7 & -1 & +1 & +1 & 6 & 26 & 152 & 49.74 \\
8 & +1 & +1 & +1 & 24 & 26 & 152 & 49.11 \\
9 & $-\alpha$ & 0 & 0 & 0 & 23 & 140 & 48.90 \\
10 & $+\alpha$ & 0 & 0 & 30 & 23 & 140 & 48.85 \\
11 & 0 & $-\alpha$ & 0 & 15 & 18 & 140 & 48.90 \\
12 & 0 & $+\alpha$ & 0 & 15 & 28 & 140 & 48.42 \\
13 & 0 & 0 & $-\alpha$ & 15 & 23 & 120 & 48.83 \\
14 & 0 & 0 & $+\alpha$ & 15 & 23 & 160 & 48.89 \\
15 & 0 & 0 & 0 & 15 & 23 & 140 & 48.43 \\
16 & 0 & 0 & 0 & 15 & 23 & 140 & 48.59 \\
17 & 0 & 0 & 0 & 15 & 23 & 140 & 48.19 \\
\hline
\end{tabular}

Where: $\alpha=1.68$; X,x are PFF (\%) in coded value and real value, respectively, Y,y are moisture content (\%) in coded value and real value, respectively, and Z,Z are temperature $\left({ }^{\circ} \mathrm{C}\right)$ in coded value and real value, respectively.

Table 5. Analysis of the effects for the response Glycemic Index (GI).

\begin{tabular}{lccrl}
\hline & Effects & Standard error & $\mathrm{t}(8)$ & $\mathrm{p}$-value \\
\hline Mean & 48.41 & 0.24 & 204.82 & $1.75 \mathrm{E}-14$ \\
$\mathrm{X}$ & -0.28 & 0.22 & -1.26 & 0.25 \\
$\mathrm{X}^{2}$ & 0.30 & 0.24 & 1.21 & 0.27 \\
$\mathrm{Y}$ & 0.01 & 0.22 & 0.05 & 0.96 \\
$\mathrm{Y}^{2}$ & 0.15 & 0.24 & 0.59 & 0.57 \\
$\mathrm{Z}^{*}$ & 0.53 & 0.22 & 2.38 & 0.05 \\
$\mathrm{Z}^{2}$ & 0.29 & 0.24 & 1.17 & 0.28 \\
$\mathrm{X} \times \mathrm{Y}$ & -0.04 & 0.29 & -0.15 & 0.89 \\
$\mathrm{X} \times \mathrm{Z}$ & 0.12 & 0.29 & 0.40 & 0.70 \\
$\mathrm{Y} \times \mathrm{Z}$ & 0.26 & 0.29 & 0.90 & 0.40 \\
\hline
\end{tabular}

* Statistically significant at a $90 \%$ significance level $(\mathrm{p}<0.10)$; X: PFF; Y: moisture content; Z: temperature (coded values).

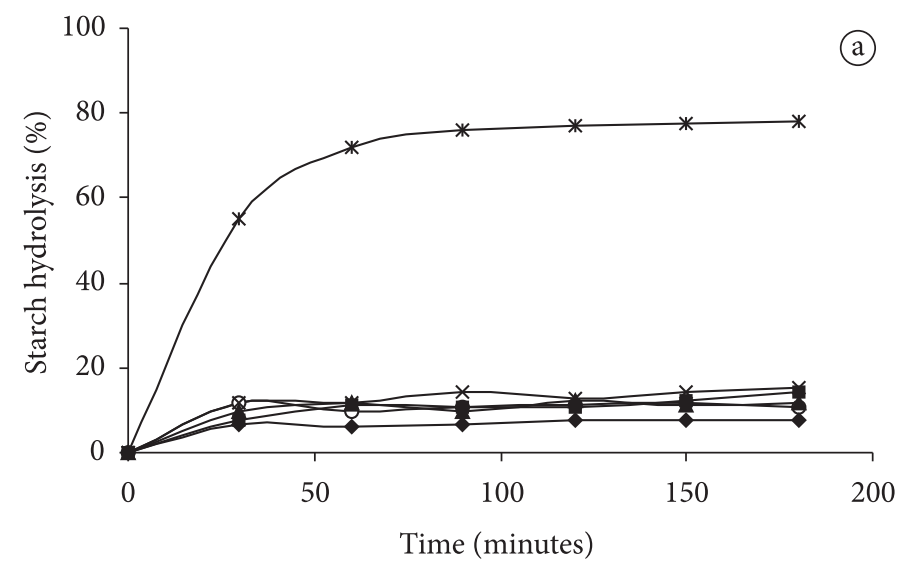

On the other hand, Assay 7, with a low PFF content (6\%) and processed under high moisture content $(26 \%)$ and temperature $\left(152^{\circ} \mathrm{C}\right)$, led to the highest GI values $(49.74)$.

Temperature influences the GI, as it promotes a higher degree of starch gelatinization and possibly dextrinization, increasing starch susceptibility to $\alpha$-amylase. One of the most important factors affecting the susceptibility of extruded starch to enzymatic hydrolysis and intestinal absorption is the degree of starch gelatinization and dextrinization that promote changes in the physicochemical properties of the extrudates, such as viscosity and solubility (MERCIER; LINKO; HARPER, 1998).

Therefore, the processes described by Assays 2 and 4 were those that led to the lowest GI values, while Assay 7 led to the highest values. These three assays were selected for the comparative study between the GI of the extrudates, white bread, and the raw materials.

\subsection{Comparison between the GI of the raw materials and of the extrudates}

The hydrolysis curves of the two raw materials and the reference (white bread) are shown in Figure 2.

It can be clearly seen that the raw materials were less digested than the reference (white bread). For corn flour, this fact is related to the structure of non-gelatinized starch. Generally, in natura grain flours contain non-gelatinized starch granules, which are resistant to enzymatic digestion (GOÑI et al., 1997), different from white bread which presents higher availability of gelatinized starch for the action of pancreatic enzymes in its composition. The rate of hydrolysis increases proportionally with the degree of starch gelatinization (CHUNG; LIM; LIM, 2006).

It can also be observed that PFF presents lower hydrolysis values when compared to corn flour; however, the difference is not great. The lower values of hydrolysis found for PFF are probably related to its total dietary fiber content.

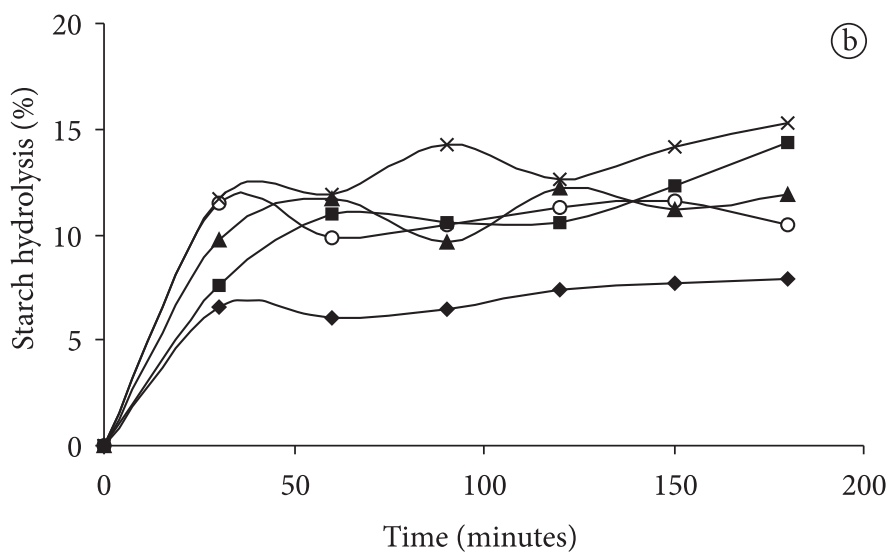

○ Corn flour $\bullet \mathrm{PFF} \wedge 2 \div 4 \times 7 *$ White bread

Figure 2. Enzymatic kinetics for in vitro glycemic index of a) corn flour, passion fruit fiber, extrudates (Assays 2, 4 and 7), and white bread; b) kinetics excluding the curve for white bread. Curve for white bread (reference) obtained from Goñi et al. (1997). $2=24 \% \mathrm{PFF}, 20 \% \mathrm{MC}, 128^{\circ} \mathrm{C}$; $4=24 \% \mathrm{PFF}, 26 \% \mathrm{MC}, 128^{\circ} \mathrm{C} ; 7=6 \% \mathrm{PFF}, 26 \% \mathrm{MC}, 152^{\circ} \mathrm{C}$. PFF = passion fruit fiber and $\mathrm{MC}=$ raw material moisture content. 
Comparing the GI values of the extrudates (Table 4) with those of the raw materials ( 48 and $45 \%$, for corn flour and PFF, respectively), a certain similarity was observed; thus, there was not a significant increase after extrusion. This could be explained by the action of the fibers involving the gelatinized starch by the formation of a polymeric matrix that made the enzymatic attack more difficult during the determination of the in vitro glycemic index, as previously described by Gourgue et al. (1994) and Chung, Lim and Lim (2006). However, Assay 9, without the addition of PFF, also presented low GI. The low GI values found in all assays could also be explained due to incomplete gelatinization and retrogradation of starch preventing the action of amylases in the starch.

In this study, the extruded products obtained from all assays can be considered "low glycemic index products", according to the classification defined by Englyst and Hudson (1996), and may be considered as a possible health food alternative for individuals on weight control diets, diabetics, or those searching for healthier eating habits.

\section{Conclusion}

All the extrudates produced in this study showed a reduction of the in vitro glycemic index of approximately $50 \%$ when compared to that of white bread and could be considered an interesting alternative to be used as extruded breakfast cereals in weight and glycemia control diets, in which a slower liberation of glucose is desired.

\section{References}

AMERICAN ASSOCIATION OF CEREAL CHEMISTS - AACC. Approved methods of the American Association of Cereal Chemists. 10. ed. Saint Paul: AACC, 2000. v. 1-2.
ASSOCIATION OF OFFICIAL ANALYTICAL CHEMISTS - AOAC. Official methods of analysis of the AOAC International. 16. ed. Arlington: AOAC International, 1995. v.1.

CHAU, C. F.; HUANG, Y. L. Characterization of passion fruit seed fibres: a potential fibre source. Food Chemistry, v. 85, p. 189-194, 2004.

CHUNG, H. J. et al. In vitro starch digestibility, expected glycemic index, and thermal and pasting properties of flours from pea, lentil and chickpea cultivars. Food Chemistry, v. 111, p. 316-321, 2008.

CHUNG, H. J.; LIM, H. S.; LIM, S. T. Effect of partial gelatinization and retrogradation on the enzymatic digestion of waxy rice starch. Journal of Cereal Science, v. 43, p. 353-359, 2006.

ENGLYST, H. M; HUDSON, G. J. The classification and measurement of dietary carbohydrates. Food Chemistry, v. 57, p. 15-21, 1996.

FERREIRA, R. E. Avaliação de parâmetros do processo de extrusão e do teor de farelo de trigo adicionado em características de "snacks" expandidos de milho. 163 f. 2006. Dissertação (Mestrado em Tecnologia de Alimentos)-Faculdade de Engenharia de Alimentos, Universidade Estadual de Campinas, Campinas, 2006.

GOÑI, I.; GARCIA-ALONSO, A.; SAURA-CALIXTO, F. A starch hydrolysis procedure to estimate glycemic index. Nutrition Research, v. 17, p. 427-437, 1997.

GOURGUE, C. et al. Effect of extrusion-cooking on the hypoglycaemic properties of citrus fibre: an in vitro study. Journal of the Science of Food and Agriculture, v. 64, p. 493-499, 1994.

MATSUURA, F. C. A. U. Estudo do albedo de maracujá e de seu aproveitamento em barra de cereais. 2005. 138 f. Tese (Doutorado em Tecnologia de Alimentos)- Faculdade de Engenharia de Alimentos, Universidade Estadual de Campinas, Campinas, 2005.

MERCIER, C.; LINKO, P.; HARPER, J. M. Extrusion cooking. 2. ed. Saint Paul: American Association of Cereal Chemists, 1998. $471 \mathrm{p}$.

ROBERTS, S. B. High-glycemic index foods, hunger, and obesity: is there a connection? Nutrition Reviews, v. 58, p. 163-169, 2000.

THEBAUDIN, J. Y. et al. Dietary fibres: nutritional and technological interest. Trends in Food Science \& Technology, v. 8, p. 41-48, 1997. 